УДК 343.21: 343.451

DOI https://doi.org/10.32837/pyuv.v0i4.629

A. О. Хлопов

orcid.org/0000-0001-5342-9183

аспірант кафедри кримінального права та кримінологї

Харківського національного університету внутрішніх справ

\title{
ПОНЯТТЯ ТА ОЗНАКИ ТАЄМНИЦІ У КРИМІНАЛЬНОМУ ПРАВІ УКРАЇНИ В РОЗРІЗІ ІНФОРМАЦІЇ ПРИВАТНОГО ХАРАКТЕРУ
}

Постановка проблеми. В умовах безпрецедентного інформаційного буму двадцять першого століття недоторканність приватного життя є і залишається однією 3 найважливіших сфер правового регулювання. Натепер охорона приватного життя людини на законодавчому рівні забезпечується цілим комплексом нормативно-правових актів. Однак цей масивний законодавчий арсенал стикається з рядом проблем, що позначаються на його ефективності. Насамперед це стосується значного розгалуження, прийняття різних актів, що часто не узгоджуються між собою та суперечать один одному. Вітчизняний законодавець надто повільно адаптується до сучасних реалій розвитку суспільних відносин. Це призводить до ситуації, коли значна частина сфер залишається не врегульованою. Від цього страждають насамперед пересічні громадяни, які позбавлені можливості захистити свої права й свободи. Слабким місцем виступає поняттєвий апарат, який не завжди має офіційні дефініції, а наявні не враховують всіх потреб.

Усунути частину проблем можна шляхом вироблення єдиних підходів до розуміння сутності тих чи інших правових категорій і понять. Успішність убезпечення сфери приватного життя від протиправного втручання в більшості своїй залежить від розуміння його змісту. Центральне місце тут посідає інформація приватного характеру як категорія, що об’єднує весь спектр окремих сфер дотичних до приватного життя сфер. Особливо актуальним це стає в контексті кримінально-правової охорони приватного життя людини, яка являє собою багатогранну сферу, до якої дотичні відносини, що, на перший погляд, не лежать в їі площині, але також мають обмежений доступ - асоціюючись з поняттями «секрет» або «таємниця». Дослідження таємниці в межах кримінального права України й притаманних їй ознак, які дотичні до інформації приватного характеру, дозволить систематизувати й локалізувати проблемні питання. Це надасть можливість виявити законодавчі прогалини й запропонувати шляхи модернізації приписів.

Метою статті є дослідження значення та сутності таємниці в межах кримінального права України, аналіз спектру притаманних їй ознак у розрізі інформації приватного характеру й формування підходів до вдосконалення поняттєвого апарату й правового регулювання.
Аналіз досліджень і публікацій. На окремі аспекти сутності й ознак таємниці в межах кримінально-правової охорони приватного життя у своїх працях звертали увагу такі науковці: М.В. Анчукова, Ю.О. Гелич, С.Г. Гордієнко, С.Л. Смельянов, Д.Ю. Кондратов, І.Б. Король, О.О. Кулініч, С.Я. Лихова, О.В. Негодченко, Л.А. Савченко, А.В. Троян, Н.В. Устименко й інші. Однак попри існування наукових розробок, що характеризують поняття таємниці, слід визнати недостатній рівень опрацювання саме інформаційного змісту приватного життя. У цьому сенсі поняття інформації приватного характеру являє особливу категорію, що об'єднує значний зріз відносин, якій властивий певний рівень таємності. Тим самим стає можливим поглянути під новим кутом на актуальні питання кримінально-правової охорони приватного життя.

Виклад основного матеріалу. Приватне життя є невіддільною частиною життєдіяльності будьякої людини й потребує охорони як із боку самої людини, так і з боку держави. Особливо актуальним це виглядає в умовах небувалого досі інформаційного буму. Уже нині розширення меж покриття мережі Інтернету й мобільного зв'язку набуло дивовижних масштабів і щорічно тільки примножується. Згідно з даними звіту Міжнародного союзу електрозв'язку, за підсумками 2019 року кількість користувачів інтернетом склала 4,1 млрд людей, або 53,6\% від всього населення, що на $5,3 \%$ більше за аналогічний показник 2018 року, водночас $97 \%$ населення проживає в межах покриття мобільним зв`язком, а $93 \%$ - в межах покриття $3 \mathrm{G}[1$, с. 1,8$]$. Це яскраво підтверджує безпрецедентну загальнодоступність до будь-якої інформації, значну частину якої складає саме приватна. Звісно, інформаційний бум, притаманний нашому століттю, підсилює потенційні ризики протиправного втручання в приватний інформаційний простір людини. Доцільно розглянути інформацію приватного характеру в розрізі поняття «таємниці» як дотичної категоpiï, що власне й покликана убезпечити інформацію від оточення. Аби оцінити вплив таємниці на інформаційний зміст приватного життя, необхідно зрозуміти поширеність цього поняття в межах законодавства. Натепер тільки чинний Кримінальний кодекс України (далі - КК України) пря- 
мо передбачає більше десятка різних таємниць. Однак з огляду на розгалуженість вітчизняного законодавства можна констатувати про кратно більшу їх кількість. Щоправда, із цього приводу серед науковців немає порозуміння. Так, О.В. Негодченко нараховує понад двадцять таємниць, левова частина яких перебуває на стадії формування, що, на думку дослідника, негативно позначається на термінології [2, с. 53]. Інший науковець, О.Ю. Поліщук, знайшов згадку про понад тридцять видів таємниць, наявних у законодавстві [3, с. 224]. С.Г. Гордієнко нараховує 36 різновидів і 17 нормативно-правових актів, що декларують різного роду конфіденційну інформацію [4, с. 233]. Такі значні розбіжності в підрахунках умовно можна пояснити декількома моментами. По-перше, посилання на таємницю маються в значній частині нормативно-правових актів, що ускладнює їх пошук і підрахунок. По-друге, поряд із таємницею існує ряд дотичних понять, які не розмежовуються між собою, чим викликається певна невизначеність і плутанина. Ситуація неоднозначна й у тому сенсі, що, як доречно відзначають окремі автори, частина таємниць не має власної дефініції. Зміст останніх можна вивести лише після комплексного аналізу нормативно-правових актів.

Нині поняття таємниці по різному визначається в науковій літературі. У тлумачних словниках воно розкривається «як те, що приховується від інших, відоме не всім: секрет (Те, що не підлягає розголошенню)» [5, с. 1434]; «те, що не пізнане, не стало відомим або ще не доступне пізнанню" [6, с. 14]. Правники ж натомість ширше розкривають це поняття, наприклад, А.А. Фатьянова характеризує його як сферу об'єктивної реальності, приховану від сприйняття та розуміння [7, с. 241]. Останнє визначення розглядає таємницю під кутом правового й соціального явища, що справедливо з огляду на суспільне значення цього поняття. Однак використання категорії таємниці в межах галузі кримінального права й особливо інституту недоторканності приватного життя доцільно конкретизувати й деталізувати.

Слід наголосити, що спроби окреслити зміст таємниці на рівні доктрини були ще на початку двадцятого століття. Так, Л.Е. Владимиров визначав таємницю як «збереження в негласності обставини, розголошення якої принесло б більше шкоди, ніж користі" [8]. Таке визначення скоріше характеризує таємницю як соціальне явище, ніж правове. Водночас дослідник прив'язує таємницю лише до обставин, конкретних фактів, тим самим звужуючи сутність таємниці, яка, в його розумінні, слугує скоріше однією з перших цеглин в архітектурі будівництва відповідного інституту. На думку I.В. Смолькової, окреслене поняття радше несе моральне, ніж правове навантаження, являючи собою принцип інтересів людської куль- тури [9, с. 12-13]. Така думка заслуговує на підтримку, адже доцільність розголошення інформації лежить у площині співвідношення оцінних понять, що нівелює саму сутність таємниці. У такому вигляді вказана дефініція скоріше придатна для вживання на рівні побутових міжособистісних відносин, ніж оперування нею на рівні закону.

Конкретніше сутність таємниці розкривається вже в розрізі приватного життя. Одні автори визначають таємницю як певного роду інформацію, розголошення (передача) якої може заподіяти шкоду інтересам її володаря [10, с. 10]. Аналогічну думку поділяють інші дослідники, наприклад, Л.О. Красавчикова [11, с. 119], В.А. Ватрас $[12$, c. 211] та інші. Проте таке формулювання виглядає сумнівним, тому що інформація не визнається апріорі таємною, вона стає такою лише за певних умов. Порядок існування такої інформації вказує на загально або обмежену іï доступність. Для того, щоб інформація стала таємною, необхідно, аби це було продиктовано відповідними актами чи волевиявлення власника (співвласників) такої інформації. У першому випадку така таємниця охороняється законом, а в другому - нормами моралі. Інше крило науковців відстоює позицію, згідно з якою поняття таємниці являє собою відповідний правовий режим. Так, М.В. Пермяков стверджує, що таємниця не є інформацією, а визначає саме правовий режим інформації $[13$, с. 83]. Окреслена позиція більш прийнятна, адже законодавство розглядає таємницю скоріше як певний стан існування інформації. Водночас сам зміст розглядається окремо. Як відзначають автори, важливе й те, що «таємниця» являє собою не тільки потужний правовий, але й соціальний інститут, виражаючи міру взаємовідносин особистості, суспільства й держави $[14$, с. 27]. Таке твердження виглядає справедливим з огляду на природне походження таємниці й притаманного людини бажання відгородити частину відомостей про себе від оточення. На цьому етапі вона має спільні риси зі сферою приватної життєдіяльності людини, адже обидві перебувають поза публічної площини. У цьому сенсі можна говорити, що таємниця вказує на певний режим існування та характеризує доступ до інформації, яка наповнює іï змістом. Тобто поняття доповнюють один одного. $\mathrm{y}$ цьому сенсі можна констатувати, що самій інформації приватного характеру притаманні ознаки таємниці, але вона нею не є, адже не передбачає наявності будь-якого правового режиму.

Не можна обійти увагою і розмежування понять «таємниця» та «секрет», які часто ототожнюються. Філолог Я.Ю. Боровик, досліджуючи лексеми «таємниця», "секрет» i «загадка», характеризує ïx як ідеографічні синоніми, що передають відтінки одного й того самого поняття [15, с. 21-23]. Продовжуючи цю думку, справедливо погодитися 
з твердженням I.В. Бондаря, на думку якого не доцільно змішувати категорії «таємниця» та «конфіденційна інформація», і навпаки, вчений ототожнює такі поняття як «таємниця» «інформація 3 обмеженим доступом» i «секрет» [16, с. 13]. $\mathrm{y}$ цьому сенсі «інформація 3 обмеженим доступом» скоріше виступає сутністю таємниці, доступ до якої обмежений волею її власника або вимогою законодавчого припису.

Іншою подібною ситуацією є співвідношення між собою понять «таємниця» та «недоторканність», які насправді мають суттєві відмінності. Так, «недоторканність» за своїм змістом характеризує неможливість втручання в життєдіяльність людини без законних на те підстав. Фактично деталізуючи відповідний режим доступу до інформації, а не режим її існування, останнє своєю чергою вже лягає в площину поняття «таємниця». Тому використання окреслених понять у тотожному сенсі буде не доцільним. Обидві категорії існують незалежно одна від одної, але водночас спільно забезпечують функціонування інституту недоторканності приватного життя. Варто зупинити увагу також на зарубіжному понятті «privacy», найбільш прийнятним вітчизняним перекладом якого є слово «приватність». В.О. Серьогш визначив, що: «прайвесі - це особлива правова категорія в англо-американській системі, яка означає таємницю та недоторканність приватного життя, інтимну сферу людини» [17]. Окреслена категорія являє собою свого роду симбіоз рівно важливих понять, тим самим підтверджуючи неможливість незаконного втручання в приватне життя з боку інших осіб або держави.

У науковій спільноті традиційно виділяють чотири аспекти приватності:

- інформаційна приватність, що містить правила збору й обігу інформації про приватне життя;

- тілесна приватність, що стосується захисту від втручань у фізичний простір людини;

- комунікаційна приватність, що характеризує питання кореспонденції, телефонних розмов та інших видів комунікацій;

- територіальна приватність, що стосується встановлення обмежень на втручання в домашнє чи інше середовище [18, с. 7].

Окреслена класифікація має велике значення, адже слугує орієнтиром для виявлення окремих аспектів приватного життя людини. Крім того, можна зробити висновок про наявність відмінностей між поняттями «приватність» і вітчизняним «приватне життя». Перше містить у собі більш розширений перелік сфер, приналежних охороні. Разом із тим поняття «правейсі» одразу передбачає статус існування та процедуру доступу до інформації про приватне життя, де окрім самого їі змісту презюмується таємність і неприпустимість розголошення. У сукупності це створює єдиний правовий механізм, натомість у вітчизняному законодавстві це скоріше паралельні процеси.

У контексті приватного життя поняття таємниці ще ширше розглядає професор І.Л. Петрухін. Він визначив право на приватне життя людини як сукупність гарантованих таємниць, серед яких варто розрізняти таємниці особисті й професійні. Останні своєю чергою похідні від особистих $[19$, с. 15]. До такого висновку можна прийти 3 огляду на аналіз змісту професійних таємниць, які власне й складають інформацію приватного характеру в тій чи іншій сфері приватного життя людини. Досить часто поряд із поняттям професійної таємниці вживають службову таємницю, але таке твердження помилкове. Адже останні мають суттєві відмінності як за наявністю особи, наділеної владними повноваженнями (посадові особи державних органів та органів місцевого самоврядування), так і за змістовим наповненням. Щодо останнього фігурує інформація в найважливіших сферах життєдіяльності суспільства й держави, що не входять до державної таємниці, але не підлягають розголошенню. Деякі автори окреслені відомості умовно називають «маленькою державною таємницею» [20, с. 39]. Інші дослідники, продовжуючи таку думку вважають за необхідне закріпити це поняття на рівні закону [21]. 3 огляду на дискусійний характер окреслених думок слід визнати, що службова таємниця суттєво відрізняється від професійної та тяжіє саме до державної.

Нині охорона окремих сфер приватного життя покладається на комплекс норм, зокрема передбачених ст. ст. $132,145,163,168,182$ КК України й іншими. Основний масив цих приписів розміщений у межах розділу V «Злочини проти виборчих, трудових та інших особистих прав і свобод людини й громадянина» КК України. Окремо зупинимося лише на ст. 182 «Порушення недоторканності приватного життя» КК України. Щодо цього слід визнати дещо невдале формулювання цієї статті, яке потребує деталізації та чіткого відмежування від суміжних злочинів. Інший момент вбачається в притаманному вітчизняному законодавству й доктрині ототожненню понять «особисте життя» та «приватне життя», які насправді співвідносяться між собою як частина й ціле, змістом яких є інформація приватного характеру. Останнє виступає родовим поняттям, об'єднуючи відомості щодо різних аспектів приватної життєдіяльності людини. У цьому сенсі поняття «таємниця приватного життя» до якого апелюють окремі науковці, зокрема 0.0. Кулініч [22, с. 94]. Окреслене не повною мірою виглядає коректним, адже автори таку таємницю асоціюють лише зі ст. 182 КК України, тим самим залишаючи без уваги інші сфери приватного життя людини, передбачені рядом інших статей кодексу. Тому важливо оперувати категорією, здатною об’єднати всі охоронювані 
права у сфері недоторканності приватного життя під егідою одного поняття, такого як «інформація приватного характеру з ознаками таємниці», що, з одного боку, визначає зміст приватного життя, а з іншого, - характеризує певний обмежений доступ до себе.

Висновки. Підсумовуючи викладене, варто відзначити, що таємниця є важливим і досить розповсюдженим правовим інститутом у межах вітчизняного законодавства. Утім, далеко не всі моменти приватного життя можна трактувати виключно з позиції таємниці. Адже остання, 3 огляду на її розкриття в межах закону, є скоріше маркером, що визначає певний правовий режим. Саме приватне життя - це насамперед сукупність певної інформації щодо непублічної життєдіяльності особи, доступ до якої не бажаний. У цьому значенні така інформація має окремі ознаки, притаманні таємниці, але нею в прямому сенсі не є. Тим самим зміст приватного життя не можливо зводити тільки до поняття таємниці або інформації. Необхідне вироблення нових підходів до закону й доктрини, які будуть відповідати на сучасні запити. Адже чинний нині КК України 3 моменту свого прийняття майже не переглядався, а норми, відповідальні за охорону сфер приватного життя особи, вже очевидно потребують осучаснення. Саме тому оперування в межах категорії приватного життя поняттям «інформація приватного характеру з ознаками» дозволить об'єднати весь інформаційний спектр непублічного життя особи в один правовий інститут. Це сприятиме спрощенню правого регулювання та точніше розкриє зміст приватного життя особи як особливого виду інформації, якому притаманні ознаки таємниці.

Варто визнати й необхідність перегляду певних положень КК України. Особливо це стосується приписів, що забезпечують охорону окремих сфер приватного життя. Насамперед це стосується наявної редакції ст. 182 КК України через конкретизацію кола охоронюваних нею відносин. Це додасть правової визначеності й усуне наявну конкуренцію між окремими нормами. Проведення такого комплексу заходів сприятиме створенню та функціонуванню ефективного правового механізму протидії незаконному втручанню в різні сфери приватного життя людини.

\section{Iimepamypa}

1. Measuring digital development Facts and figures 2019. International Telecommunication Union. Geneva. 2019. P. 15. URL: https://www.itu.int/en/ITU-D/ Statistics/Documents/facts/FactsFigures2019.pdf.

2. Негодченко О.В. Інформація 3 обмеженим доступом в процесі взаємодії суб'єктів владних повноважень та громадських об'єднань. Право і суспільство. 2013. № 1. C. 48-57. URL: http://nbuv.gov.ua/UJRN/ Pis_2013_1_10.
3. Поліщук О.Ю. Поняття та ознаки інформації з обмеженим доступом. Молодь у юридичній науиі : збірник тез доповідей міжнародної наукової конференції молодих вчених «Треті осінні юридичні читання». Хмельницький : В-во ХУУП, 2004. С. 224-226.

4. Гордієнко С.Г. Конфіденційна інформація та «таємниці»: їх співвідношення. Часопис Київського університету права. 2013. № 4. С. 233-238. URL: http://nbuv.gov.ua/UJRN/Chkup 2013 4557.

5. Великий тлумачний словник сучасної української мови (з дод. І допов.) / уклад. і голов. ред. В.Т. Бусел. Київ - Ірпінь : Перун, «ВТФ», 2005. 1728 с.

6. Словник української мови : в 11 тт. / АН УРСР. Інститут мовознавства ; за ред. І.К. Білодіда. Київ : Наукова думка, 1970-1980. Т. 10 : Т - Ф. 1979. 658 с.

7. Фатьянова А.А. Тайна как социальное и правовое явление. Ее виды. Государство и право. 1998. № 6. С. 241 .

8. Владимиров Л.Е. Учение об уголовных доказательствах. Санкт-Петербург : Изд-е книжн. магазина Законоведение, 1910. 304 с.

9. Смолькова И.В. Проблемы охраняемой законом тайны в уголовном процессе : дис. ... д-ра юрид. наук : 12.00.09. Иркутск, 1998. 404 с.

10. Устименко Н.В. Таємниці особистого життя людини та їх цивільно-правова охорона : автореф. дис... канд. юрид. наук : 12.00 .03 ; Нац. юрид. акад. України ім. Я.Мудрого. Харків, 2001. 20 с.

11. Красавчикова Л.О. Личная жизнь граждан под охраной закона. Москва : Юрид. лит., 1983.160 с.

12. Ватрас В.А. До питання про поняття сімейних правовідносин. Держава і право. Вип. 23. Київ, 2004. С. 371.

13. Пермяков М.В. Категория «тайна» в системе правового регулирования : дис. ... канд. юрид. наук : 12.00.01. Екатеринбург, 2006. 234 с.

14. Головкин Р.Б. Правовое и моральное регулирование частной жизни в современной России : автореф. дис. ... д-ра юрид. наук : 12.00.01. Нижний Новгород, $2005.57 \mathrm{c}$.

15. Боровик Я.Ю. Синонімічний аспект вербалізації концепту «таємниця» в українській лінгвокультурі. Наукові записки Національного університету «Острозька акаделія». Серія «Філологічна». 2012. Вип. 24. С. 21-23. URL: http://nbuv.gov.ua/UJRN/ Nznuoaf_2012_24_9.

16. Бондарь И.В. Тайна по российскому законодательству (проблемы теории и практики) : автореф. дис. ... канд. юрид. наук : 12.00 .01 . Нижний Новгород, 2004.27 c.

17. Серьогш В.О. Прайвесі як право бути залишеним у спокої. Радник : український юридичний портал. URL: http://radnuk.info/statti/249-tioriua-gov/ 14799----l---r.html (дата звернення: 20.09.2020).

18. Privacy and Human Rights: An International Survey of Privacy Laws and Developments. Global Internet Liberty Campaign, 1998. P. 7.

19. Петрухин И.Л. Личные тайны (человек и власть). Москва : Изд-во ИГиП РАН, 1998. 232 с.

20. Скулиш Є.Д. Охоронювана інформація в кримінальному процесі. Правове, норлативне та метрологічне забезпечення системи захисту інформаиї в Україні : науково-технічний збірник. 2009. Вип. 1 (18). C.35-43.URL:https://ela.kpi.ua/bitstream/123456789/ 9762/3/10.pdf.

21. Турченяк O.M., Тугарова О.К. Сучасний стан національної системи захисту інформації з обмеженим доступом. Міжнародний науковий журнал «Інтернаука». 2019. № 3. URL: https://www.inter-nauka.com/ uploads/public/15523260165156.pdf. 
22. Кулініч 0.0. Таємниця приватного життя як виду інформації з обмеженим доступом. Актуальні проблеми держави і права. 2008. Вип. 31. С. 92-97.

\section{Анотація}

Хлопов $A . O$. Поняття та ознаки таємниці у кримінальному праві України в розрізі інформації приватного характеру. - Стаття.

У статті досліджується сутність поняття таємниці й притаманних їй ознак у кримінальному праві України в розрізі інформації приватного характеру. Розглядаються погляди науковців щодо розуміння таємниці й співвідношення різних її видів між собою. Аналізується правова природа інформації приватного характеру крізь властиві таємниці ознаки. Пропонується вироблення єдиних правових підходів, здатних спростити правове регулювання кримінально-правової охорони приватного життя та окремих її сфер.

Розглядаються різні аспекти приватної життєдіяльності людини, що підпадають під охорону з боку кримінально-правових норм. У цьому сенсі вивчено ряд дотичних до приватного життя понять, що розкривають зміст та окремі його аспекти. Пропонуються шляхи вдосконалення наявного натепер поняттєвого апарату. Детально аналізуються наукові погляди й етимологія поняття таємниці, особливо в контексті приватного життя, 3 урахуванням наявних законодавчих підходів. Підтверджується незадовільний стан справ у сфері правового регулювання та існування стійкого запиту на модернізацію значного масиву законодавства. Насамперед це стосується Кримінального кодексу України, адже після його прийняття норми, відповідальні за охорону окремих аспектів приватного життя, майже не переглядалися. Це дозволяє сумніватися в можливості цих приписів ефективно відповідати на сучасні суспільні виклики. Особливо в умовах швидкого розвитку суспільних відносин та інформаційного буму двадцять першого століття, чим створюються додаткові ризики протиправного використання будь-яких відомостей, у тому числі приватного характеру.

У висновку підтверджується переконливість думки, що забезпечення охорони різних аспектів приватного життя не може зводитися лише до однієї статті кодексу. Окреслена категорія є більш багатогранною 3 великою кількістю дотичних до неї сфер життя. У підсумку констатується, що інформація приватного характеру має ознаки таємниці, але нею не є. Водночас вона найбільш спроможна консолідувати всі сфери приватного життя в межах одного правового інституту, сприяючи його осучасненню.
Ключові слова: таємниця, інформація, інформація приватного характеру, інформація з обмеженим доступом, приватність, приватне життя.

\section{Summary}

Khlopov $A$. $O$. The concept and signs of secrecy in the criminal law of Ukraine in the context information of private character. - Article.

The article examines the essence of the concept of secrecy and its inherent features in the criminal law of Ukraine in the context of information of private character. The views of scientists to the understanding of secrets and the relationship of its various types to each other are considered. The legal nature of information of private character is analyzed through the characteristics of a secret. It is proposed to develop unified legal approaches that can simplify the legal regulation of criminal legal protection of private life and its individual spheres.

Separately, various aspects of the private life of a person are considered that are protected by criminal law. In this sense, a number of concepts related to private life have been studied, revealing the content and its individual aspects. The ways of improving the existing conceptual apparatus are proposed. Scientific views and etymology of the concept of secrecy are analyzed in detail, especially in the context of private life, taking into account the existing legislative approaches. The unsatisfactory state of affairs in the field of legal regulation and the existence of a stable demand for the modernization of a significant body of legislation are confirmed. First of all, this concerns the Criminal Code of Ukraine, because after the adoption of the norm, those responsible for the protection of certain aspects of private life were hardly revised. This raises doubts about the possibility of these regulations to effectively respond to modern social challenges. Especially in the context of the rapid development of public relations and the information boom of the twenty-first century, which creates additional risks of unlawful use of any information, including of a private nature.

The conclusion confirms the persuasiveness of the idea that ensuring the protection of various aspects of private life cannot be reduced to just one article of the code. The designated category is more multifaceted with a large number of spheres of life tangent to it. As a result, it is stated that information of private character has signs of a secret, but it is not. Moreover, it is most capable of consolidating all spheres of private life within one legal institution, contributing to its modernization.

Key words: secret, information, information of private character, information with limited access, privacy, private life. 